\title{
Grasses and legumes in mixture: an energy intercropping system intended for anaerobic digestion
}

\author{
Giuseppe Gatta, ${ }^{1}$ Anna Gagliardi, ${ }^{1}$ Pietro Soldo, ${ }^{2}$ Massimo Monteleone ${ }^{1}$ \\ ${ }^{1}$ Dipartimento di Scienze Agro-ambientali, Chimica e Difesa Vegetale, Università di Foggia, Italy; \\ ${ }^{2}$ Consorzio per la Bonifica della Capitanata, Foggia, Italy
}

\begin{abstract}
Batch testing of biomethanization was conducted on organic matrices from a mixture of grasses (triticale and barley) and legumes (field bean - Vicia faba L. var. minor). These tests were performed in mesophylic conditions $\left(35^{\circ} \mathrm{C}\right)$ on previously chopped and ensiled biomass.

The three crops have been cultivated in Southern Italy (Puglia region), both as single-crops and intercropping between triticale or barley and field bean, in different mixture combinations, during the season 2009-2010. Emphasis was placed on the determination of the chemical composition of feedstock from the three single species and their different intercropping ratios, mowed at two subsequent stages (milk and dough development of grasses), also assessing their consequent biogas and methane potential yields after silage. Seven overall treatments have been compared: the three species in monoculture (triticale, barley and field bean, respectively); two mixtures between triticale and field bean (with triticale at 70 and $50 \%$, respectively); two mixtures between barley and field bean (again with barley at 70 and $50 \%$, respectively). Immediately after cutting and for the next 90 days, biomass samples were closed into plastic mini-silos, each having a 5L capacity, in order to simulate the silage process. Thereafter, the batch testing was performed and biogas and methane production have
\end{abstract}

Correspondence: Giuseppe Gatta, Dipartimento di Scienze Agro-ambientali, Chimica e Difesa Vegetale, Università di Foggia, via Napoli 25, 71100 Foggia, Italy.

Tel.+39.0881.589238. E-mail: g.gatta@unifg.it

Key words: biogas, biomethane, grasses and legumes, intercropping systems.

Conference presentation: SIA Congress, Bari 2012.

Acknowledgments: the authors are grateful to the reviewers whose comments and suggestions have helped in improving the standard of this manuscript. This work has been funded by the Puglia region, Consorzio per la Bonifica della Capitanata of Foggia (Italy), Agroservice S.p.A., ISEA S.r.L. and Fondazione Banca del Monte of Foggia (Italy).

Received for publication: 24 September 2012.

Revision received: 28 January 2013.

Accepted for publication: 4 February 2013.

(C) Copyright G. Gatta et al., 2013

Licensee PAGEPress, Italy

Italian Journal of Agronomy 2013; 8:e7

doi:10.4081/ija.2013.e7

This article is distributed under the terms of the Creative Commons Attribution Noncommercial License (by-nc 3.0) which permits any noncommercial use, distribution, and reproduction in any medium, provided the original author(s) and source are credited. been determined, with respect to the main chemical characteristics of the chopped and ensiled biomass samples, able to affect biogas and methane yield. Considering the single-crop treatments the highest biogas per hectare production has been found with respect to triticale $\left(8737.1 \mathrm{~nm}^{3} \mathrm{ha}^{-1}\right)$ and barley $\left(8837.6 \mathrm{~nm}^{3} \mathrm{ha}^{-1}\right)$, at the first and second harvesting stage, respectively. Concerning grass-legume intercropping, the highest biogas yield $\left(8635.0 \mathrm{~nm}^{3} \mathrm{ha}^{-1}\right)$ was observed with reference to the 70:30 mixing ratio, specifically on barley mowed at the milk development stage. The methane content in the biogas ranged from $61.1 \%$ (on a 50:50 mixing ratio of barley at the milk stage) to $53.7 \%$ (on a barley monoculture at the dough stage).

\section{Introduction}

Anaerobic digestion (AD) is the process of organic matter decomposition by a microbial consortium in an oxygen-free environment resulting in biogas. Biogas obtained from agricultural feedstock is generally composed of $48-65 \%$ methane, $36-41 \%$ carbon dioxide, up to $17 \%$ nitrogen, $32-169$ ppm hydrogen sulphide and traces of other gases (Kala, 2011; Ward et al., 2008). Biogas from biomass might ensures new opportunities for the agricultural sector and provide additional farm income. Moreover, AD can also be considered a favourable form of waste management including agricultural, municipal, food industry wastes as well as fresh plant residues. Another remarkable advantage of $\mathrm{AD}$ is that the digestion effluent (digestate) can be used as a valuable fertiliser for agricultural crops.

Biogas can be produced from a wide range of energy crops; differently from feedstock derived from residues and waste, in this case biogas production has a higher demand for arable land. Therefore, the aim to achieve is the highest possible methane yield per unit of agricultural area $\left(\mathrm{m}^{3} \mathrm{ha}^{-1}\right)$. This overall methane yield consists of two multiplicative factors (Prochnow et al., 2009): the biomass organic dry matter yield $\left(\mathrm{kg} \mathrm{ODM} \mathrm{ha}^{-1}\right)$ and the feedstock specific methane yield $\left(\mathrm{m}^{3} \mathrm{~kg} \mathrm{ODM}^{-1}\right)$. To ensure a sustainable biomass production from energy crops, they need to be grown in ecologically balanced and diversified crop rotation systems. With respect to energy crops, intercropping can represent a key factor in improving the efficiency of cultivation systems (Vandermeer, 1989; Pristeri et al., 2006). In particular, intercropping of grasses with legumes has a large application for the production of fodder and forage, the two species being complementary in the use of nitrogen (Jensen, 1996). Generally, grass-legume intercropping shows a more efficient use of nutrients and other ecological resources than their corresponding sole-crops (Hauggaard-Nielsen $e t$ al., 2006). Legumes provide various benefits to agricultural soils, such as increase soil nitrogen content, improve soil structure, lessen the incidence of pests and diseases, boost soil stability and prevent its erosion (Senaratne and Hardarson, 1988; Chalk, 1998).

Key factors for a high biogas potential yield are, therefore, the prop- 
er choice of crop species and varieties and their nutrient composition (Amon et al., 2006, 2007; Herrmann et al., 2007). The development stage at the time of herbage mowing can significantly affect the biomass water content, the amount of dry biomass harvestable and its biochemical composition. Crude proteins, crude fats, crude fibres, cellulose, hemicelluloses, starch and sugars markedly influence the production of methane (Amon et al., 2002, 2003, 2004; Balsari et al., 1983). The most suitable feedstock should be very rich in easily degradable carbohydrates, such as sugars, but poor in hemicelluloses and lignin, which have low biodegradability (El Bassam, 1998). Protein microbial degradation produces nitrogen in the form of ammonia; its concentrations below $200 \mathrm{mg} / \mathrm{L}$ are beneficial, since nitrogen is an essential microbial nutrient (Liu and Sung, 2002), however, high total ammonia level (from 1.7 to $14 \mathrm{~g} / \mathrm{L}$ ) can lead up to $50 \%$ reduction in methane production (Chen et al., 2008; Sung and Liu, 2003).

The focus of the present research was to determine optimal mixtures of herbage crops as feedstock for AD through biomass ensiling, in order to increase the specific methane yield and methane yield per agricultural surface unit. More specifically, the objectives of the research were: i) to assess methane production of different crop and inter-cropping systems (two winter grasses and a legume); ii) to evaluate the effects of two different mowing stages on biomass production and its biochemical composition, also detecting the corresponding methane yield with respect to different feedstock mixtures; iii) to statistically characterize the quality of feedstock (according to its biochemical composition) with respect to the experimental treatments (crop system and mowing stage).

\section{Materials and methods}

\section{Site characteristics and treatments}

The field trial was carried out during the growth season 2009-2010 in an agricultural area of Southern Italy (Ascoli Satriano: $41^{\circ} 14^{\prime}$ $\mathrm{N}, 15^{\circ} 30^{\prime} \mathrm{E}$, altitude $283 \mathrm{~m}$ asl). The climate of this area is typical of a Mediterranean regions with a long-term average of annual rainfall equal to $550 \mathrm{~mm}$, mainly concentrated between October and April. The trial was carried out on a loam soil (USDA), with $\mathrm{pH} 7.8,2.1 \%$ of organic matter content, total nitrogen 0.94 ppm, P (Olsen method) 85 ppm and K 140.2 ppm.

Two winter grasses, barley (Hordeum vulgare L. cv. Oleron) and triticale (Triticum aestivum L. $x$ Triticosecàle W. cv. Catria) and one legume, field bean (Vicia faba L. var. minor cv. Chiaro di Torrelama) were cultivated as single-crops and as grass-legume mixtures in two seeding ratios (i.e., 70:30 and 50:50 by weight). The seeding rate both for grasses and legume monoculture was $220 \mathrm{~kg} \mathrm{ha}^{-1}$ (corresponding to 420,390 and 47 viable seeds $\mathrm{m}^{-2}$ for barley, triticale and bean), while the seeding rates for grass-legume intercropping were: 154 and $66 \mathrm{~kg}$ $\mathrm{ha}^{-1}$ for 70:30 seeding ratio, 110 and $110 \mathrm{~kg} \mathrm{ha}^{-1}$ for $50: 50$ seeding ratio.

All crops were sown in the second decade of November. The pre-sowing fertilization rates were $27 \mathrm{~kg}$ nitrogen $(\mathrm{N}) \mathrm{ha}^{-1}$ and $69 \mathrm{~kg}$ phospho- rus $(\mathrm{P}) \mathrm{ha}^{-1}$, for all treatments, while a top dressing of $46 \mathrm{~kg} \mathrm{~N} \mathrm{ha}^{-1}$ was applied at the early stem-elongation stage of grasses, in this latter case excluding the legume monoculture.

The crops were mowed by hand. Shoots were cut approximately $5 \mathrm{~cm}$ above the soil, between the first (I-05) and third (III-05) decade of May. Mowing, both for grass monoculture and grass-legume intercropping was performed at two subsequent mowing stages (MS): the milk $\left(\mathrm{H}_{1}\right)$ and dough $\left(\mathrm{H}_{2}\right)$ development stages of grasses (Zadok et al., 1974), respectively. Differently, for legume monoculture the first mowing $\left(\mathrm{H}_{1}\right)$ was performed at the flowering stage and the second one $\left(\mathrm{H}_{2}\right)$ when about the $60 \%$ of pods had reached the final length (Stulpanagel, 1984).

Seven cropping systems (CS) were compared in factorial combination with the two MS. The experimental treatments are reported in Table 1.

The aforementioned treatments were arranged according to a split plot experimental design with three replications (blocks), considering the seven CS in the main plots and the two MS in the subplots. Each main plot had an area of $48 \mathrm{~m}^{2}$ (6 $\mathrm{m}$ long by $8 \mathrm{~m}$ wide). The aboveground biomass was entirely harvested from each subplot $\left(24 \mathrm{~m}^{2}\right)$ and its weight was then recorded. A subsample of fine chopped biomass was collected from the total mass. Afterward an aliquot of $1.5 \mathrm{~kg}$ was dried at $70^{\circ} \mathrm{C}$ to constant weight to determine the biomass dry matter content ( $\mathrm{g} \mathrm{kg}^{-1}$ fresh matter). Approximately $250 \mathrm{~g}$ of dried forage were then used for subsequent laboratory analysis. A remaining fresh biomass amount of each subplot sample (exactly corresponding to $3.5 \mathrm{~kg}$ of fresh matter) was hand chopped (reducing the feedstock to particles of 3-5 $\mathrm{mm}$ ) and then pressed in a 5-L plastic mini-silos, in order to simulate the process of silage. Compression was done by hand using a pressing device that ensured the same conditions for all the samples. The minisilos were stored at $25^{\circ} \mathrm{C}$ for a period of 90 days; additives or starter to promote ensiling were not applied.

\section{Measurements and analytical methods}

Prior to anaerobic digestion experiments, each feedstock sample was analysed according to the following standard methods.

Moisture content was determined by drying at $105^{\circ} \mathrm{C}$ until constant weight was reached. The ash content (XA) was calculated through an incineration process at $550^{\circ} \mathrm{C}$ for $6 \mathrm{~h}$ (AOAC, 1990). $\mathrm{pH}$ was measured with the electrode $\mathrm{PH} \&$ Ion-Meter GLP22 ${ }^{+}$after homogenizing $5 \mathrm{~g}$ of sample with $100 \mathrm{~mL}$ distilled water for a period of $30 \mathrm{~min}$.

For further analysis an adequate amount of feedstock was dried at a temperature of $60^{\circ} \mathrm{C}$ and grinded in a cutting mill. The C:N ratio was determined using an elemental analyser (vario EL, Analysen systeme $\mathrm{GmbH}$, Hanau, Germany) operating according to the principle of catalytic combustion under the supply of oxygen at high temperatures. Elemental analysis was conducted according to the DUMAS method (DIN, 2006-07). Total nitrogen (TN) was determined using the Kjeldahl method (AOAC, 2000), quantifying the amount of nitrogen using a selective ammonium electrode. Crude protein content (XP) was then calculated by multiplying TN by the coefficient 6.25 . Ether extract $(\mathrm{XL})$ was measured after an extraction procedure on the sample with a Soxhlet device (AOAC, 1990). Starch content (XT) was quantified

Table 1. Experimental treatments resulting from the factorial combination of seven cropping systems and two mowing stages.

\begin{tabular}{|c|c|c|c|c|c|c|c|}
\hline MS & & & & $\mathrm{CS}^{\#}$ & & & \\
\hline $\mathrm{H1}$ & $\mathrm{B}_{100(\mathrm{Hl})}$ & $\mathrm{T}_{100(\mathrm{Hl})}$ & $\mathrm{L}_{100}(\mathrm{HI})$ & $\mathrm{T}_{70}-\mathrm{L}_{30}(\mathrm{Hl})$ & $\mathrm{T}_{50}-\mathrm{L}_{50}(\mathrm{Hl})$ & $\mathrm{B}_{70}-\mathrm{L}_{30}(\mathrm{Hl})$ & $\mathrm{B}_{50}-\mathrm{L}_{50}(\mathrm{Hl})$ \\
\hline $\mathrm{H} 2$ & $\mathrm{~B}_{100(\mathrm{H} 2)}$ & $\mathrm{T}_{100(\mathrm{H} 2)}$ & $\mathrm{L}_{100}$ (H2) & $\mathrm{T}_{70}-\mathrm{L}_{30}(\mathrm{H} 2)$ & $\mathrm{T}_{50}-\mathrm{L}_{50}(\mathrm{H} 2)$ & $\mathrm{B}_{70}-\mathrm{L}_{30}(\mathrm{H} 2)$ & $\mathrm{B}_{50}-\mathrm{L}_{50}(\mathrm{H} 2)$ \\
\hline
\end{tabular}

${ }^{\circ}$ First mowing stage $\left(\mathrm{H}_{1}\right)$ and second mowing stage $\left(\mathrm{H}_{2}\right) ;{ }^{\sharp} 100 \%$ triticale $\left(\mathrm{T}_{100}\right) ; 100 \%$ barley $\left(\mathrm{B}_{100}\right) ; 100 \%$ field bean $\left(\mathrm{L}_{100}\right) ; 70 \%$ triticale and $30 \%$ field bean $\left(\mathrm{T}_{70}-\mathrm{L}_{30}\right) ; 50 \%$ triticale and $50 \%$ field bean $\left(\mathrm{T}_{50}-\mathrm{L}_{50}\right) ; 70 \%$ barley and $30 \%$ field bean $\left(\mathrm{B}_{70}-\mathrm{L}_{30}\right) ; 50 \%$ barley and $50 \%$ field bean $\left(\mathrm{B}_{50}-\mathrm{L}_{50}\right)$. CS, cropping systems; MS, mowing stages. 
according to the method of saccharification using hydrochloric acid (Balestrieri and Marini, 1996). Sugar (XZ) was extracted from $10 \mathrm{~g}$ of raw material in $100 \mathrm{~mL}$ of distilled water (Dolciotti et al., 1998). After filtration the amount of water soluble carbohydrates was quantified according to Fehling method (De Clerk, 1963). Neutral-detergent fibre, acid-detergent fibre, hemicellulose (HC), cellulose (CL) and aciddetergent lignin (ADL) were analysed according to the detergent system procedure (Goering and van Soest, 1970). Crude fibre (XF) was analyzed according to the Weende methods (AOAC, 1990).

\section{Anaerobic digestion batch testing}

Biogas and methane production was detected through an anaerobic digestion batch testing procedure, according to DIN 38414 (1985). The layout of the equipment used to perform such tests is shown in Figure 1. The system was composed by 8 two-L bioreactors, a gasometer for measuring the produced biogas and a biogas analyzer (GA2000Plus, Geotechnical instruments, Warwickshire, UK). A programmable logic controller allowed the automatic regulation of the procedure. Each bioreactor was equipped with probes to check and record the main parameters of the anaerobic digestion process $(\mathrm{pH}$, temperature, redox potential, etc.). The tests were carried out in water at a controlled temperature in mesophilic conditions $\left(35 \pm 1^{\circ} \mathrm{C}\right)$. The starter (inoculum) was collected from a biogas plant, co-digesting corn-silage and cattle-slurry at the same temperature conditions. The ratio between chopped feedstock and starter was 1:2 (on dry basis). The yield of methane from each treatment was evaluated in three replications. The main chemical characteristics of the starter are reported in Table 2. A batch test was also performed on the starter alone, i.e. without any feedstock, in order to determine the baseline. Indeed, the methane yielded from this latter test was routinely subtracted from the methane production of each other treatment. The batch fermentation tests were carried out until methane production was negligible (the daily biogas yield was equivalent to only $1 \%$ of the total biogas produced until that time). On this respect, a running time of 45 days was considered appropriate. The produced biogas was continuously collected in a gas-meter and daily measured.

\section{Statistical data analysis}

The measured data from each of the response variable were statistically processed through analysis of variance (ANOVA), according to the applied experimental design and considering the two experimental factors, CS and MS, in factorial combination. When significant effects were detected $(\mathrm{P}<0.05)$, means multiple comparison was performed according to the Tukey's test (honestly significant difference).

Furthermore, the variables related to the chemical composition of silage were jointly considered in a multivariate approach and statistically processed applying a canonical analysis with the two experimental factors (CS and MT) as discriminating sources (Sadocchi, 1981; Stagnari et al., 2007). The first two canonical variables, accounting for the larger part of the data variability, were considered for further data interpretation. All data were analysed by software JMP (SAS Institute Inc., Cary, NC, USA) package version 8.2.

\section{Results}

\section{Weather conditions}

The rain amount recorded during the trial (November 2009 to June 2010) was $449.5 \mathrm{~mm}$ and the average maximum and minimum temperature were $17.4^{\circ} \mathrm{C}$ and $7.3^{\circ} \mathrm{C}$ (Figure 2).

Harvesting was performed at milk and dough development stages of grasses, during the first (I-05) and third (III-05) decade of May, when the maximum and minimum temperatures were $21.9^{\circ} \mathrm{C}-11.2^{\circ} \mathrm{C}$ and $26.4^{\circ} \mathrm{C}-12.7^{\circ} \mathrm{C}$.

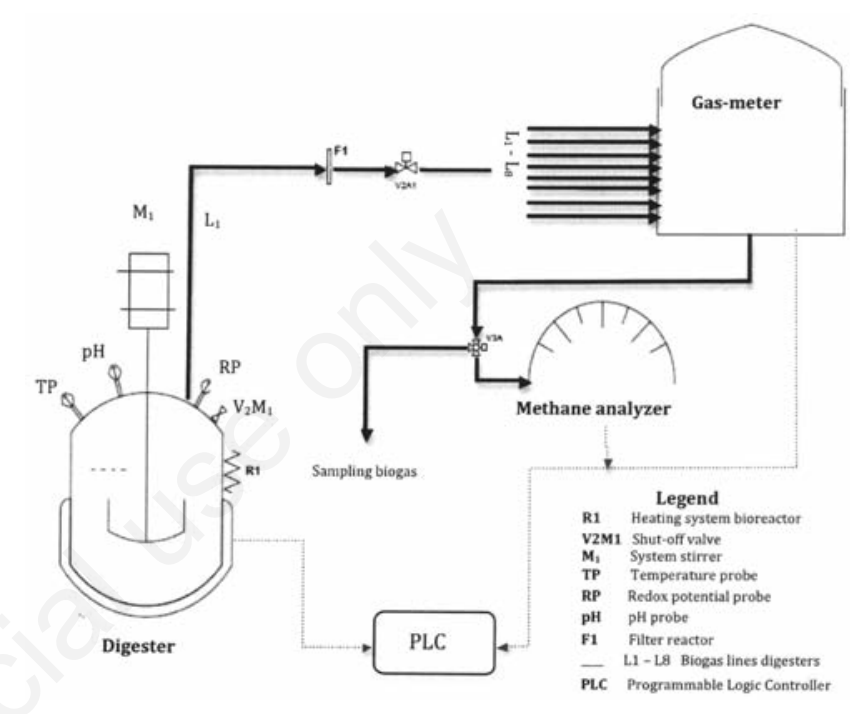

Figure 1. Layout of the equipment used in the batch testing procedure.

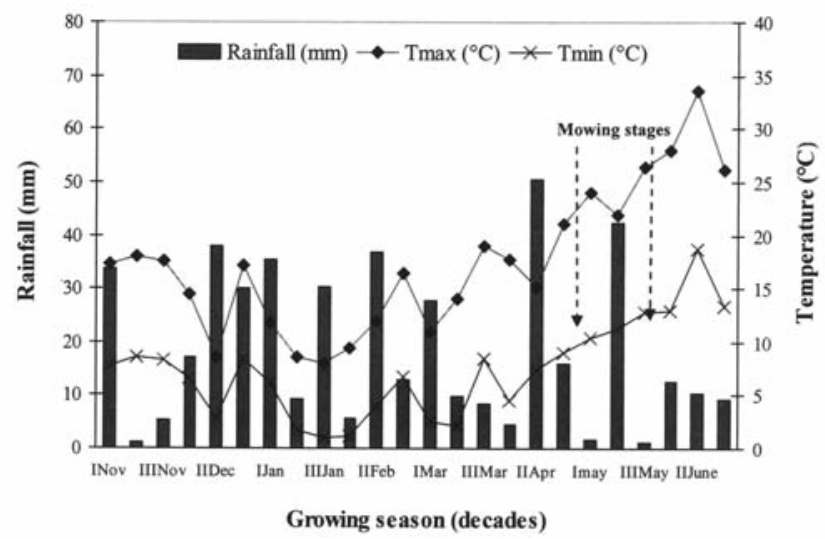

Figure 2. Time course of the minimum and maximum air temperatures and rainfall, from sowing to harvesting, considering subsequent 10-day periods during the growing season.

Table 2. Main chemical characteristics of the starter (inoculum).

\begin{tabular}{ccccccc} 
NS & N $(\%$ DM) & C (\% DM) & C/N (-) & pH (-) & DM (\% FM) & VS (\% DM) \\
7 & $6.1(0.4)$ & $29.2(2.3)$ & $4.7(0.5)$ & $7.6(0.6)$ & $2.9(0.4)$ & $51.7(0.9)$ \\
\hline
\end{tabular}

NS, number of samplings; $N$, nitrogen; C, carbon; DM, dry matter; C/N, ratio; FM, fresh matter; VS, volatile solids. In brackets standard deviations are reported. 


\section{Fresh and dry matter yield}

The ANOVA results on fresh (FM) and dry matter (DM) of biomass, are reported on Table 3. CS and MS had a significant effect either alone and in interaction.

Biomass FM decreased from the first $\left(\mathrm{H}_{1}\right)$ to the second $\left(\mathrm{H}_{2}\right)$ mowing stages but displaying a different trend with respect to treatments. The highest FM value at $\mathrm{H}_{1}$ was in $\mathrm{L}_{100}\left(48.1 \mathrm{mg} \mathrm{ha}^{-1}\right)$, also confirmed at $\mathrm{H}_{2}\left(40.3 \mathrm{mg} \mathrm{ha}^{-1}\right)$. Considering the two grass species in monoculture, barley $\left(\mathrm{B}_{100}\right)$ showed a higher fresh productivity than triticale $\left(\mathrm{T}_{100}\right)$ at $\mathrm{H}_{1}$, while the reverse condition was observed at $\mathrm{H}_{2}$. This behaviour was also recorded with respect to the intercropping treatments, but with a decreasing effect as the rate of grasses in the mixture decreased (from $70 \%$ to 50\%). The lowest FM value was recorded at $\mathrm{H}_{2}$ with respect to $\mathrm{B}_{100}\left(29.5 \mathrm{mg} \mathrm{ha}^{-1}\right)$, a value not statistically different from the other grass-legume mixtures harvested at $\mathrm{H}_{2}$.

Biomass DM generally decreased in proportion to the amount of legume in the mixture: it was higher with respect to grasses in monoculture $\left(\mathrm{T}_{100}\right.$ and $\left.\mathrm{B}_{100}\right)$ and progressively lower across the 70:30 and 50:50 mixing ratios, to reach the lowest recorded values in $\mathrm{L}_{100}$, both at $\mathrm{H}_{1}$ and $\mathrm{H}_{2}$ (8.8 and $9.3 \mathrm{mg} \mathrm{ha}^{-1}$, respectively). $\mathrm{H}_{2}$ was generally more productive than $\mathrm{H}_{1}$. The highest DM value at $\mathrm{H}_{2}$ was observed in $\mathrm{T}_{100}$ $\left(13.6 \mathrm{mg} \mathrm{ha}^{-1}\right)$, not significantly different from $B_{100}\left(13.3 \mathrm{mg} \mathrm{ha}^{-1}\right)$. Still considering $\mathrm{H}_{2}$, the $\mathrm{B}_{70}-\mathrm{L}_{30}$ treatment showed a significantly higher DM value $\left(12.7 \mathrm{mg} \mathrm{ha}^{-1}\right)$ with respect to the other $70: 30$ mixing treatment, thus accounting for the significance of the interaction CS $\times$ MS.

Similarly to DM, DM content ( $\mathrm{g} \mathrm{kg}^{-1}$ ) decreased with an increasing percentage of legume in the mixture; this trend was especially noticeable at $\mathrm{H}_{2}$ compared to $\mathrm{H}_{1}$ and, considering $\mathrm{H}_{2}$, more relevant for barley (B) than for triticale (T). The highest recorded value was for $\mathrm{B}_{100}-\mathrm{H}_{2}$ $\left(451 \mathrm{~g} \mathrm{~kg}^{-1}\right)$, while the lowest one was for $\mathrm{L}_{100}-\mathrm{H}_{1}\left(182 \mathrm{~g} \mathrm{~kg}^{-1}\right)$.

\section{Chemical composition of the ensiled biomass}

Table 4 shows the average chemical composition of the ensiled biomass (expressed on dry basis, DM) with respect to the two experimental factors, CS and MS, as well as their interaction.

$\mathrm{XA}$ content showed the highest values in legume as a single-crop $\left(\mathrm{L}_{100}\right)$, irrespective of the two mowing stages (106.9 and $109.6 \mathrm{~g} \mathrm{~kg}^{-1}$ at $\mathrm{H}_{1}$ and $\mathrm{H}_{2}$ respectively). Lower values were observed considering the other treatments, specifically $\mathrm{T}_{70}-\mathrm{L}_{30}$ at $\mathrm{H}_{2}\left(62.6 \mathrm{~g} \mathrm{~kg}^{-1}\right)$.

The $\mathrm{pH}$ values significantly increased from the first $\left(\mathrm{H}_{1}\right)$ to the second $\left(\mathrm{H}_{2}\right)$ harvesting. $\mathrm{L}_{100}$ at $\mathrm{H}_{2}$ showed the highest value (7.1) while $\mathrm{L}_{100}$ at $\mathrm{H}_{1}$ the lowest (5.2). At $\mathrm{H}_{1}, \mathrm{pH}$ values were relatively stable across treatments; differently, at $\mathrm{H}_{2}$, they progressively increased with an increasing legume ratio in the mixture; this behavior was sharper for barley than triticale.

XP concentration was, on average, higher at $\mathrm{H}_{1}$ than at $\mathrm{H}_{2}$ (85.2 vs $77.9 \mathrm{~g} \mathrm{~kg}^{-1}$ ). Its value was higher for legume as a single-crop (129.6 g $\mathrm{kg}^{-1}$ ) and gradually decreased with the reduction of the legume in the mixture, reaching its lowest value for $\mathrm{T}_{100}$ and $\mathrm{B}_{100}$ (68.7 and $62.4 \mathrm{~g} \mathrm{~kg}^{-1}$ respectively).

$\mathrm{XF}$ showed the highest values for single-legume $\left(\mathrm{L}_{100}\right)$, irrespective of the two mowing stages (424.7 and $417.5 \mathrm{~g} \mathrm{~kg}^{-1}$ at $\mathrm{H}_{1}$ and $\mathrm{H}_{2}$ respectively). Considering the other treatments, the fibre content usually decreased from the first to the second harvest $\left(\mathrm{H}_{1}\right.$ vs $\left.\mathrm{H}_{2}\right)$ and from triticale to barley (T vs B). Differently from the general behavior, at $\mathrm{H}_{1}$, treatment $B_{70}-L_{30}$ showed a fibre content higher than the corresponding $\mathrm{T}_{70}-\mathrm{L}_{30}$.

CL content was significantly affected by the mowing stage: higher values indeed were detected at $\mathrm{H}_{1}$ compared with $\mathrm{H}_{2}$ (594.6 and $496.1 \mathrm{~g}$ $\mathrm{kg}^{-1}$ on average, respectively). Again, single-legume $\left(\mathrm{L}_{100}\right)$ showed a higher CL content than all the other treatments $\left(613.2 \mathrm{~g} \mathrm{~kg}^{-1}\right)$.

Concerning to $\mathrm{HC}$ content, the only significant effect was due to the MS factor; the average $\mathrm{HC}$ values of the two harvest stages were 139.8 and $190.2 \mathrm{~g} \mathrm{~kg}^{-1}$ at $\mathrm{H}_{1}$ and $\mathrm{H}_{2}$, respectively.

ADL content decreased, on average, from $\mathrm{H}_{1}$ to $\mathrm{H}_{2}$. Considering the grasses in monoculture, at $\mathrm{H}_{2}, \mathrm{~B}_{100}$ was significantly higher $(27.7 \mathrm{~g}$ $\mathrm{kg}^{-1}$ ) than the expected values. At $\mathrm{H}_{1}$, pure legume $\left(\mathrm{L}_{100}\right)$ showed the highest ADL value, statistically different with respect to all the other treatments, while triticale in mixture showed quite higher values than in monoculture, higher than the other intercropping treatments.

With respect to carbon-nitrogen ratio $(\mathrm{C} / \mathrm{N})$, a general trend of decreasing $\mathrm{C} / \mathrm{N}$ values with a decreasing grass contribution to the mixture was remarked, along with a slight tendency to higher $\mathrm{C} / \mathrm{N}$ values at $\mathrm{H}_{1}$ compared to $\mathrm{H}_{2}$. An unexpectedly high $\mathrm{C} / \mathrm{N}$ value (45.9) was

Table 3. Effects of cropping systems and mowing stages, in factorial combination, on fresh and dry matter of biomass, together with its dry matter content.

\begin{tabular}{|c|c|c|c|}
\hline Treatments & $\begin{array}{c}\text { FM } \\
{\left[\mathrm{mg} \mathrm{ha}^{-1}\right]}\end{array}$ & $\begin{array}{c}\text { DM } \\
{\left[\mathrm{mg} \mathrm{ha}^{-1}\right]}\end{array}$ & $\begin{array}{l}\text { DM content } \\
{\left[\mathrm{g} \mathrm{kg}^{-1} \mathrm{FM}\right]}\end{array}$ \\
\hline \multicolumn{4}{|l|}{ CS } \\
\hline $\mathrm{T}_{100}$ & $37.0^{\mathrm{b}}$ & $13.0^{\mathrm{a}}$ & $353^{\mathrm{ab}}$ \\
\hline $\mathrm{B}_{100}$ & $36.4^{\mathrm{bc}}$ & $12.9^{\mathrm{a}}$ & $370^{\mathrm{a}}$ \\
\hline $\mathrm{L}_{100}$ & $44.2^{\mathrm{a}}$ & $9.0^{\mathrm{e}}$ & $206^{\mathrm{e}}$ \\
\hline $\mathrm{T}_{70}-\mathrm{L}_{30}$ & $34.0^{c}$ & $10.9^{c}$ & $322^{c}$ \\
\hline $\mathrm{T}_{70}-\mathrm{L}_{70}$ & $35.5^{\mathrm{bc}}$ & $10.6^{\mathrm{cd}}$ & $302^{\mathrm{d}}$ \\
\hline $\mathrm{B}_{70}-\mathrm{L}_{30}$ & $35.4^{\mathrm{bc}}$ & $12.1^{\mathrm{b}}$ & $347^{\mathrm{b}}$ \\
\hline $\mathrm{B}_{70}-\mathrm{L}_{70}$ & $35.2^{\mathrm{bc}}$ & $10.3^{\mathrm{d}}$ & $295^{\mathrm{d}}$ \\
\hline \multicolumn{4}{|l|}{ MS } \\
\hline $\mathrm{H}_{1}$ & $40.3^{\mathrm{a}}$ & $10.92^{\mathrm{b}}$ & $274^{b}$ \\
\hline $\mathrm{H}_{2}$ & $33.4^{\mathrm{b}}$ & $11.63^{\mathrm{a}}$ & $353^{\mathrm{a}}$ \\
\hline \multicolumn{4}{|l|}{$\mathrm{CS} \times \mathrm{H}$} \\
\hline $\mathrm{T}_{100(\mathrm{HI})}$ & $38.8^{\mathrm{bcd}}$ & $12.4^{\mathrm{cd}}$ & 319 cde \\
\hline $\mathrm{B}_{100(\mathrm{HI})}$ & $43.4^{\mathrm{ab}}$ & $12.6^{\mathrm{bc}}$ & $290^{\text {efg }}$ \\
\hline $\mathrm{L}_{100}(\mathrm{Hl})$ & $48.1^{\mathrm{a}}$ & $8.8^{\mathrm{h}}$ & $182^{\mathrm{i}}$ \\
\hline $\mathrm{T}_{70}-\mathrm{L}_{30}(\mathrm{Hl})$ & $35.3^{\mathrm{de}}$ & $10.5^{\mathrm{fg}}$ & 299 def \\
\hline $\mathrm{T}_{70}-\mathrm{L}_{70}(\mathrm{Hl})$ & $38.5^{\text {cd }}$ & $10.3^{g}$ & $26 f^{f g}$ \\
\hline $\mathrm{B}_{70}-\mathrm{L}_{30}$ (HI) & $38.8^{\mathrm{bcd}}$ & $11.6^{\mathrm{de}}$ & $300^{\text {def }}$ \\
\hline $\mathrm{B}_{70}-\mathrm{L}_{70}$ (HI) & $39.1^{\mathrm{bcd}}$ & $10.2^{g}$ & $261^{\text {gh }}$ \\
\hline $\mathrm{T}_{100 \text { (H2) }}$ & $35.2^{\mathrm{de}}$ & $13.6^{\mathrm{a}}$ & $387^{b}$ \\
\hline $\mathrm{B}_{100(\mathrm{H} 2)}$ & $29.5^{\mathrm{f}}$ & $13.3^{a b}$ & $451^{\mathrm{a}}$ \\
\hline $\mathrm{L}_{100}(\mathrm{H} 2)$ & $40.3^{b c}$ & $9.3 \mathrm{~h}$ & $231^{\mathrm{h}}$ \\
\hline $\mathrm{T}_{70}-\mathrm{L}_{30}(\mathrm{H} 2)$ & $32.7^{\mathrm{ef}}$ & $11.2^{\mathrm{ef}}$ & $344^{c}$ \\
\hline $\mathrm{T}_{70}-\mathrm{L}_{70}(\mathrm{H} 2)$ & $32.5^{\mathrm{ef}}$ & $10.9^{\text {efg }}$ & $336^{c}$ \\
\hline $\mathrm{B}_{70}-\mathrm{L}_{30}$ (н2) & $32.1^{\mathrm{ef}}$ & $12.7^{\mathrm{bc}}$ & $395^{\mathrm{b}}$ \\
\hline $\mathrm{B}_{70}-\mathrm{L}_{70}$ (H2) & $31.3^{\text {ef }}$ & $10.3^{g}$ & $329^{\mathrm{cd}}$ \\
\hline \multicolumn{4}{|l|}{ Significance } \\
\hline $\mathrm{CS}$ & $* * *$ & $* * *$ & $* * *$ \\
\hline MS & $* * *$ & $* * *$ & $* * *$ \\
\hline $\mathrm{CS} \times \mathrm{H}$ & $* *$ & $*$ & $* * *$ \\
\hline
\end{tabular}

${ }_{\mathrm{a}-\mathrm{f}}$ In each column, means followed by equal letters are not significantly different for $\mathrm{P}<0.05$ (Tukey's test); ${ }^{*} \mathrm{P} \leq 0.05 ;{ }^{* *} \mathrm{P} \leq 0.01 ;{ }^{* * *} \mathrm{P} \leq 0.001$. FM, fresh matter; DM, dry matter; CS, cropping systems; $\mathrm{MS}$, mowing stages. 


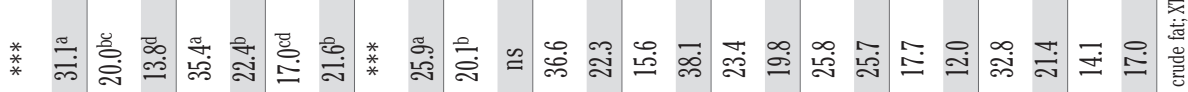

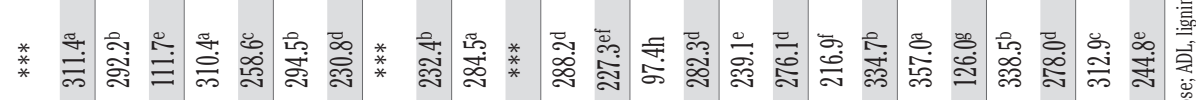

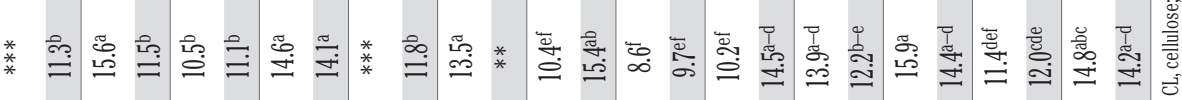

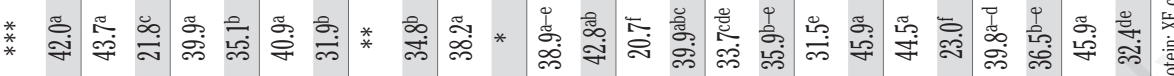

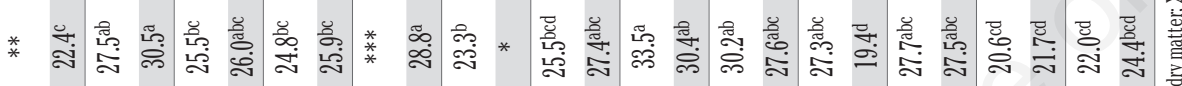

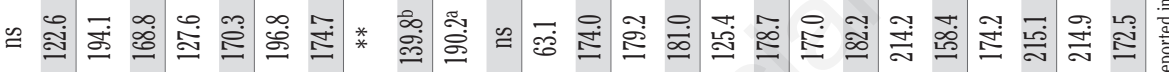

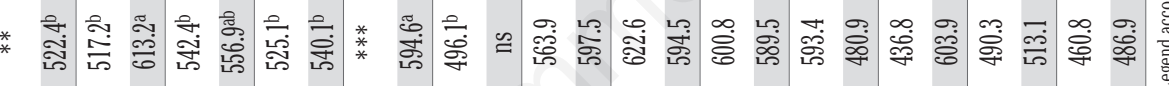

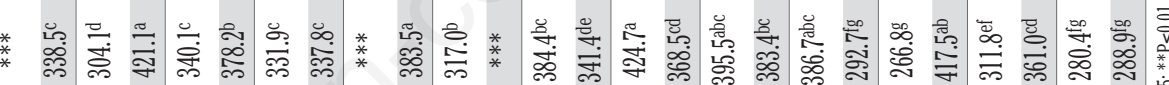

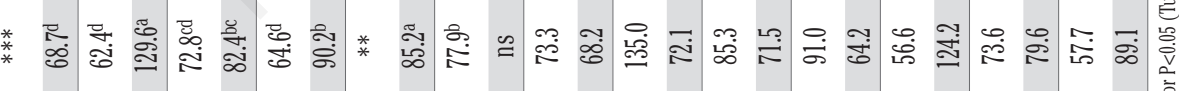

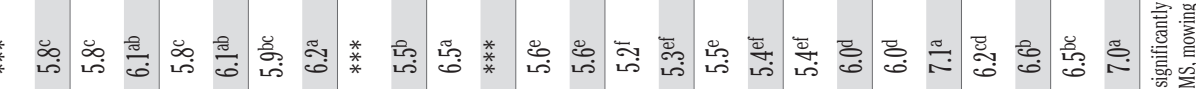

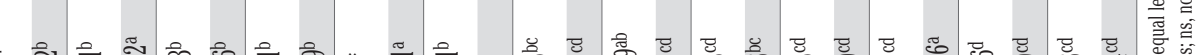

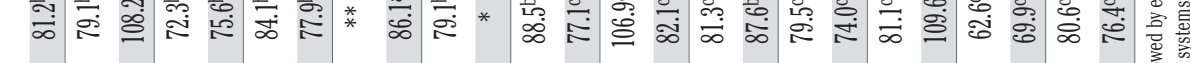


observed in $\mathrm{B}_{70}-\mathrm{L}_{30}$ at $\mathrm{H}_{2}$, the highest observed values, although not significantly different from $\mathrm{T}_{100}$ and $\mathrm{B}_{100}$ at the same $\mathrm{H}_{2}$ harvesting time (45.8 and 44.5, respectively). The lowest value (20.7) was observed in $\mathrm{L}_{100}$, at $\mathrm{H}_{1}$, although it was not statistically different from the corresponding value at $\mathrm{H}_{2}$ (23.0).

The highest values in fat content (XL) was observed considering the biomass from barley, both as a monoculture or as a mixture, and with respect to the first $\left(\mathrm{H}_{1}\right)$ as well as to the second $\left(\mathrm{H}_{2}\right)$ harvesting stage (these values ranged between 15.9-13.9 $\mathrm{g} \mathrm{kg}^{-1}$ ). A similar value (14.4 g $\mathrm{kg}^{-1}$ ) was also observed considering legume as a single-crop $\left(\mathrm{L}_{100}\right)$ at $\mathrm{H}_{2}$, while at $\mathrm{H}_{1} \mathrm{XL}$ reached the lowest value $\left(8.6 \mathrm{~g} \mathrm{~kg}^{-1}\right)$. Considering the triticale treatments, the second harvesting stage showed slightly higher XL values (11.9 $\mathrm{g} \mathrm{kg}^{-1}$ on average) than the first one $\left(10.1 \mathrm{~g} \mathrm{~kg}^{-1}\right.$ on average).

XT content showed its lowest values from legume as a single-crop ( $\mathrm{L}_{100}$ ): 97.4 and $126.0 \mathrm{~g} \mathrm{~kg}^{-1}$ at $\mathrm{H}_{1}$ and $\mathrm{H}_{2}$, respectively. The treatments harvested at $\mathrm{H}_{2}$ are systematically higher than those harvested at $\mathrm{H}_{1}$; this effect is more relevant considering single-crop grasses than mixtures. The starch content of barley as a single-crop $\left(B_{100}\right)$ increased of $36.3 \%$, ranging from 227.3 to $357.0 \mathrm{~g} \mathrm{~kg}^{-1}$. Considering triticale $\left(\mathrm{T}_{100}\right)$ and legume $\left(\mathrm{L}_{100}\right)$ as single-crops XT increased of $22.7 \%$ and $13.9 \%$, respectively. With respect to the grass-legume intercropping treatments, the XT content decreased with the increasing rate of legume in the mixture. On average, the $\mathrm{XZ}$ content was higher at $\mathrm{H}_{1}\left(25.9 \mathrm{~g} \mathrm{~kg}^{-1}\right)$ than $\mathrm{H}_{2}\left(20.1 \mathrm{~g} \mathrm{~kg}^{-1}\right)$. The treatments $\mathrm{T}_{100}$ and $\mathrm{T}_{70}-\mathrm{L}_{30}$ showed the highest values (31.1 and $35.4 \mathrm{~g} \mathrm{~kg}^{-1}$, respectively) while for $\mathrm{L}_{100}$ the lowest value was recorded $\left(13.8 \mathrm{~g} \mathrm{~kg}^{-1}\right)$.

\section{Canonical analysis on the chemical composition of the ensiled biomass}

Considering the high degree of correlation between several variables characterizing the chemical composition of biomass (thus pointing out a significant redundancy of the dataset), a statistical multivariate approach was applied to a selection of these variables (8 out of 11), eliminating those variables that showed a correlation coefficient higher than 0.9 with the selected variables.

The first two extracted canonicals accounted for the $94 \%$ of the total variance: $65 \%$ for the first and $30 \%$ for the second one. On Table 5 is showed that the first canonical variable is strongly correlated with $\mathrm{XP}, \mathrm{XF}$, XA and CL biomass content; while a high inverse correlation with XT is also displayed. The second canonical variable, instead, is correlated with $\mathrm{XZ}$ content and, in a more limited extent, inversely correlated to HC.

The same considerations, pertaining to the biomass chemical composition and related to Table 5 , can be easily derived from the observation of the biplot graphs (Figures 3 and 4), considering the length and orientation of the vectors. The two biplots represent the effects exerted by the discriminating experimental factors (SC and MS, respectively) on the qualitative characteristics of the ensiled biomass. In the first biplot (Figure 3), the most relevant observation is the clear discrimination between legume (in the upper part of the graph) and grasses (in the lower one). Considering the first canonical axes, the high XP content of legume as single-crop led to a very high positive score; grasslegume mixtures are mainly located in the central part of the graph, showing values close to zero; while grasses in monoculture showed a negative score that is mostly related both to a limited protein content but also to a relative higher level of starch and a lower level of ashes. The second canonical axes is quite efficient in the discrimination between the two grass species, barley and triticale respectively; triticale, both as single-crop $\left(\mathrm{T}_{100}\right)$ and intercropping $\left(\mathrm{T}_{70}\right.$ and $\left.\mathrm{T}_{50}\right)$, is characterized by a relatively higher $\mathrm{XZ}$ and $\mathrm{XF}$ content, while barley $\left(\mathrm{B}_{100}\right.$, $\mathrm{B}_{70}$ and $\mathrm{B}_{50}$ ), by a higher amount of lipid fraction (XL) and $\mathrm{HC}$.
The second biplot (Figure 4), allows the discrimination of the two mowing stages (at milk and dough development stage, respectively). From the first $\left(\mathrm{H}_{1}\right)$ to the second $\left(\mathrm{H}_{2}\right)$ harvesting, it can be observed a marked increase in XL content and a correspondingly decrease in XF. To a lesser extent, it can be observed a decrease in XZ content and an increase in HC.

Significantly high inverse correlations were detected between the first canonical variable (as a qualitative index of the ensiled biomass) and some of the quantitative production variables. More specifically, the highest correlations $\left(\mathrm{R}=-0.84^{* *}\right.$ and $\left.-0.71^{* *}\right)$ were found with respect to the per hectare dry biomass production and the per hectare biogas yield (Table 6). Lower degree of correlations (not statistically significant) were detected with respect to the second canonical variable. Figure 5 clearly shows the higher productive potential of triticale and barley as single-crops, at the second harvesting stage, mainly due to their higher content in XT and XL and a correspondingly lower amount of XP and XA. An opposite behaviour was found in legumes in monoculture, not only at the first harvesting stage $\left(\mathrm{H}_{1}\right)$ but also in the second one $\left(\mathrm{H}_{2}\right)$.

\section{Biogas and methane yields}

Statistical analysis (ANOVA) has pointed out significant differences in biogas and methane yields, both with respect to single experimental factors (CS and MS) as well as their interaction (Table 7).

Table 5. Standardised coefficients of the first two canonical variables considering the chemical properties of the ensiled biomass. The corresponding percentages of variation accounted for is also reported.

\begin{tabular}{lcc}
$\begin{array}{l}\text { Chemical composition } \\
\text { of ensiled biomass }\end{array}$ & \multicolumn{2}{c}{ Standardised coefficients } \\
& CAN 1 & CAN 2 \\
XA & 0.75 & -0.25 \\
XP & 0.93 & -0.17 \\
\hline XF & 0.86 & 0.31 \\
CL & 0.74 & 0.33 \\
\hline HC & -0.18 & -0.59 \\
XL & -0.39 & -0.45 \\
\hline XT & -0.95 & 0.21 \\
XZ & -0.25 & 0.91 \\
\hline Percentage explained variation & 64.9 & 29.3 \\
Percentage cumulative variation & 64.9 & 94.2 \\
\hline
\end{tabular}

CAN, canonical variables; $\mathrm{XA}$, ash; $\mathrm{XP}$, crude protein; $\mathrm{XF}$, crude fibre; CL, cellulose; $\mathrm{HC}$, hemicellulose; $\mathrm{XL}$, crude fat; XT, starch; XZ, sugar.

Table 6. Correlations between the first two canonical variables related to biomass chemical quality and the quantitative variables related to biomass or biogas production.

\begin{tabular}{lcc} 
Quantitative variables & CAN 1 & CAN 2 \\
Biogas yield $\left(\mathrm{nm}^{3} \mathrm{ha}^{-1}\right)$ & -0.71 & 0.23 \\
FM $\left(\mathrm{mg} \mathrm{ha} \mathrm{h}^{-1}\right)$ & 0.78 & 0.11 \\
\hline DM $\left(\mathrm{mg} \mathrm{ha}^{-1}\right)$ & -0.84 & -0.02 \\
CAN 1 & 1.00 & -0.00 \\
\hline CAN 2 & -0.00 & 1.00 \\
\hline
\end{tabular}

CAN, canonical variables; FM, fresh matter; DM, dry matter. 
Table 7. Effects of cropping systems and mowing stages, in factorial combination, on biogas and methane yields (ANOVA results).

\begin{tabular}{|c|c|c|c|c|c|c|c|c|}
\hline \multirow[t]{2}{*}{ Sources of variation } & \multicolumn{4}{|c|}{ Yield [ $\left.\mathrm{nm}^{3} \mathrm{mg}_{\mathrm{vs}}^{-1}\right]$} & \multicolumn{4}{|c|}{ Production $\left[\mathrm{nm}^{3} \mathrm{ha}^{-1}\right]$} \\
\hline & DF & SQ & $\mathrm{F}$ & Probability & DF & SQ & F & Probability \\
\hline \multicolumn{9}{|l|}{ Biogas } \\
\hline CS & 6 & $75,008,964$ & 44.2 & $<0.0001$ & 6 & $143,875.7$ & 13.8 & $<0.0001$ \\
\hline MS & 1 & 538,722 & 1.9 & 0.1890 & 1 & $39,707.5$ & 22.9 & 0.0003 \\
\hline $\mathrm{CS} \times \mathrm{MS}$ & 6 & $14,309,745$ & 8.4 & 0.0005 & 6 & $171,498.3$ & 16.5 & $<0.0001$ \\
\hline \multicolumn{9}{|l|}{ Methane } \\
\hline CS & 6 & $24,884,094$ & 55.1 & $<0.0001$ & 6 & $61,662.3$ & 21.9 & $<0.0001$ \\
\hline MS & 1 & 576,726 & 7.6 & 0.0151 & 1 & $21,683.0$ & 46.3 & $<0.0001$ \\
\hline CS x MS & 6 & $4,714,968$ & 10.4 & 0.0002 & 6 & $54,654.1$ & 19.5 & $<0.0001$ \\
\hline
\end{tabular}

DF, Degrees of freedom; SQ, sum of squares; F, F ratio; CS, cropping systems; MS, mowing stages.

The specific biogas yields (i.e. the amount of biogas obtained per unit weight of volatile solids and expressed in $\mathrm{nm}^{3} \mathrm{mg}_{\mathrm{vs}}{ }^{-1}$ ) generally decreased from $\mathrm{H}_{1}$ to $\mathrm{H}_{2}$, with the exception of $\mathrm{B}_{100}$ and $\mathrm{L}_{100}$ treatments (Figure 6). Significant differences were observed in $\mathrm{T}_{100}$ (from 772.6 to $621.2 \mathrm{~nm}^{3} \mathrm{mg}_{\mathrm{vs}}{ }^{-1}$ ), $\mathrm{B}_{70}-\mathrm{L}_{30}$ (from 819.1 to $570.5 \mathrm{~nm}^{3} \mathrm{mg}_{\mathrm{vs}}{ }^{-1}$ ) and $\mathrm{B}_{50}-\mathrm{L}_{50}$ (from 711.6 to $565.3 \mathrm{~nm}^{3} \mathrm{mg}_{v s}{ }^{-1}$ ). $\mathrm{B}_{70} \mathrm{~L}_{30}$ allowed to record the highest biogas yield $\left(819.1 \mathrm{~nm}^{3} \mathrm{mg}_{v s^{-1}}\right)$, while $\mathrm{L}_{100}$ the lowest one $\left(444.5 \mathrm{~nm}^{3}\right.$ $\mathrm{mg}_{\mathrm{vs}}{ }^{-1}$ ), both at the $\mathrm{H}_{1}$ stage.

Specific methane yield $\left(\mathrm{nm}^{3} \mathrm{mg}_{\mathrm{vs}}{ }^{-1}\right)$ offered, approximately, the same considerations (Figure 7). The yield obtained by triticale-legume intercropping $\left(\mathrm{T}_{70}-\mathrm{L}_{30}\right.$ e $\left.\mathrm{T}_{50}-\mathrm{L}_{50}\right)$, at the first harvesting stage, resulted not statistically different from the yield obtained by triticale as a singlecrop $\left(\mathrm{T}_{100}\right)$. A different behaviour was observed considering the yield of methane from barley-legume mixture in the first harvesting stage $\left(\mathrm{B}_{70^{-}}\right.$ $\mathrm{L}_{30}$ e $\mathrm{B}_{50}-\mathrm{L}_{50}$ ), with statistically higher values ( 472.4 and $435 \mathrm{~nm}^{3} \mathrm{mg}_{\mathrm{vs}}{ }^{-1}$ ) than the ones related to barley in monoculture $\left(384.8 \mathrm{~nm}^{3} \mathrm{mg}_{\mathrm{vs}}{ }^{-1}\right)$.

In Figure 8 the per hectare biogas production $\left(\mathrm{nm}^{3} \mathrm{ha}^{-1}\right)$ is also reported. Biogas production is the result of per hectare dry matter production and biogas yield per tons of dry matter. The influence of CS and MS on biogas production was similar but lower than the one already shown considering the biogas yield. Legume and grasses in monoculture $\left(\mathrm{L}_{100}\right.$ or $\left.\mathrm{T}_{100}\right)$ showed biogas yields ranging between 3482.4 to $5078.9 \mathrm{~nm}^{3} \mathrm{ha}^{-1}$ and 8737.1 to $7853.0 \mathrm{~nm}^{3} \mathrm{ha}^{-1}$, respectively at the first and second harvesting stage, but this temporal differences were not statistically significant. Triticale at the $\mathrm{H}_{1}$ stage, and barley at $\mathrm{H}_{2}$, both as monoculture, reported higher biogas production (8737.1 and 8837.6 $\mathrm{nm}^{3} \mathrm{ha}^{-1}$, respectively), while considering grass-legume intercropping, higher methane productions were detected for $\mathrm{B}_{70}-\mathrm{L}_{30}$ at $\mathrm{H}_{1}\left(8635.0 \mathrm{~nm}^{3}\right.$ $\mathrm{ha}^{-1}$ ). The methane content in the biogas ranged from $61.1 \%$ for $\mathrm{B}_{50}-\mathrm{L}_{50}$ $\left(\mathrm{H}_{1}\right)$ to $53.7 \%$ for $\mathrm{B}_{100}\left(\mathrm{H}_{2}\right)$ (results not shown). In Figure 9 the per hectare methane yields is reported. The yield of triticale in monoculture at the first harvest stage $\left(5221.1 \mathrm{~nm}^{3} \mathrm{ha}^{-1}\right)$ was not statistically different with respect to the second one $\left(4493.2 \mathrm{~nm}^{3} \mathrm{ha}^{-1}\right)$, while triticale-legume intercropping at $\mathrm{H}_{1}$ stage yielded a statistically lower values (4093.5 and $3891.0 \mathrm{~nm}^{3}$ ha $^{-1}$ for $\mathrm{T}_{70}-\mathrm{L}_{30}$ and $\mathrm{T}_{50}-\mathrm{L}_{50}$, respectively) with respect to triticale as a single-crop.

\section{Discussion}

The DM yields of triticale as herbage crop obtained from this study is roughly in accordance with other researches carried out in different Italian regions, like Sardegna (Delogu et al., 2002) and the Po valley (Bocchi et al., 1996). Triticale as monocultures showed, in our condi-

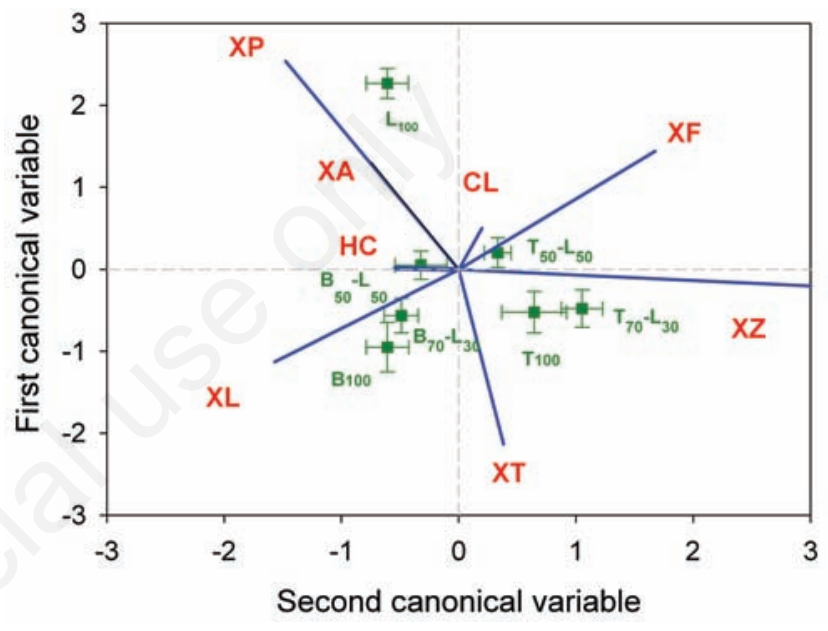

Figure 3. Canonical analysis on the chemical composition of the ensiled biomass discriminating the seven cropping system treatments. XA, ash; XP, crude protein; XF, crude fibre; $C L$, cellulose; HC, hemicelluloses; XL, crude fat; XT, starch; XZ sugar. Triticale $\left(\mathrm{T}_{100}\right)$, barley (B100) and broad bean (L100); $70 \%$ triticale and $30 \%$ broad bean $\left(\mathrm{T}_{70}-\mathrm{L}_{30}\right), 50 \%$ triticale and $50 \%$ broad bean $\left(\mathrm{T}_{50}-\mathrm{L}_{50}\right) ; 70 \%$ barley and $30 \%$ broad bean $\left(\mathrm{B}_{70}-\mathrm{L}_{30}\right), 50 \%$ barley and $50 \%$ broad bean $\left(\mathrm{B}_{50}-\mathrm{L}_{50}\right)$.

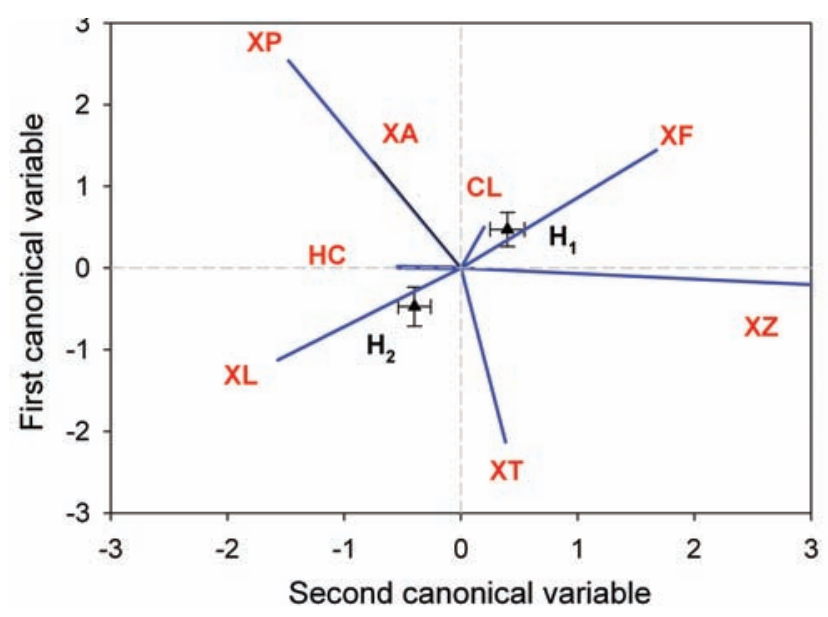

Figure 4. Canonical analysis on the chemical composition of the ensiled biomass discriminating the two mowing stages. XA, ash; $\mathrm{XP}$, crude protein; XF, crude fibre; $\mathrm{CL}$, cellulose; HC, hemicelluloses; XL, crude fat; XT, starch; XZ sugar. First mowing stage $\left(\mathrm{H}_{1}\right)$, second mowing stage $\left(\mathrm{H}_{2}\right)$. 
tions, a slightly higher yield than in the reference studies.

FM yields recorded for legume (field bean) as herbage crop were higher compared with other researches (Ghanbari-Bonjar and Lee, 2003). Quite certainly, these differences may be due to the different genetic constitution of the cultivars used and to different pedo-environmental conditions of the cultivation areas. On the other side, the dry matter production obtained with legume in monoculture and intercropping are comparable with the data reported by the same authors (Ghanbari-Bonjar and Lee, 2003). Similarly to our results, they also have shown that DM and FM yields of intercropped legume (wheatbeans) were greater than DM and FM legume as monoculture.

On average, DM has increased of $12.3 \%$ from the first to the second harvesting. As reported by Delogu et al. (2002), this behavior was expected and may be interpreted as the crop growth completion toward the end of its cycle, which proceeds with the storing of newly-formed photosynthates into the grain.

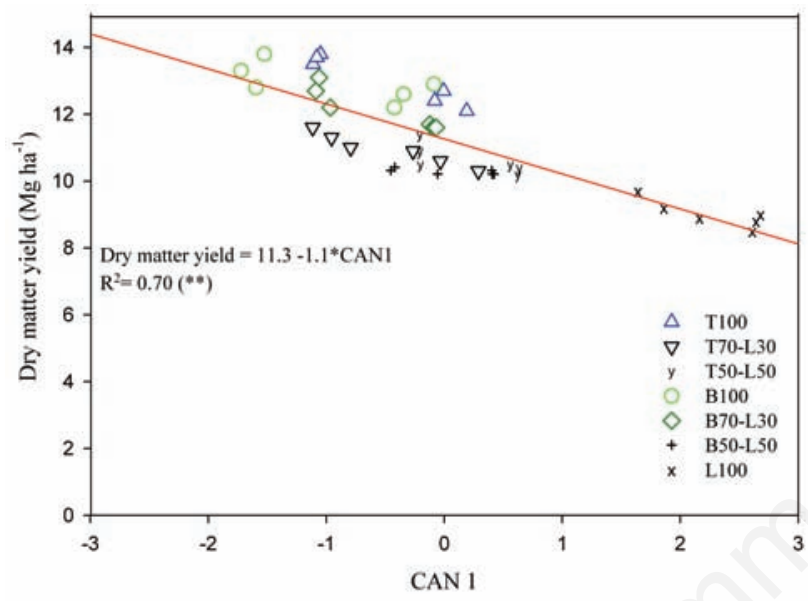

Figure 5. Linear regression of dry matter yield (considered as a quantitative trait of the ensiled biomass) with respect to the first canonical variable (a multivariate qualitative index of the ensiled biomass).

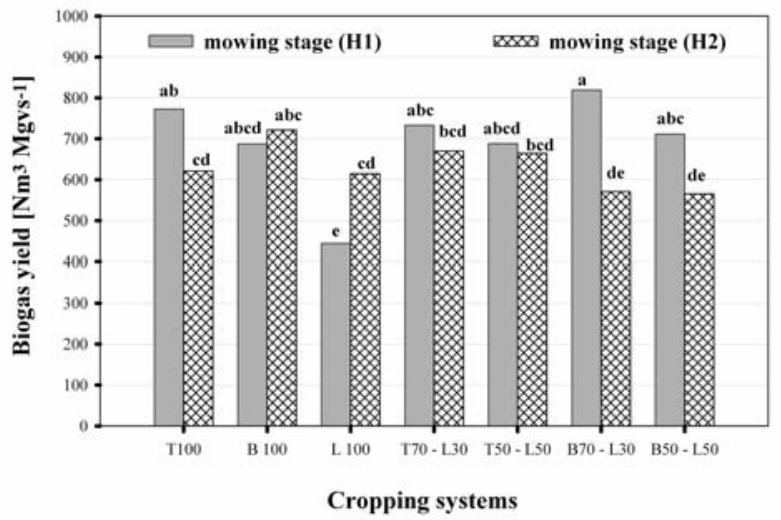

Figure 6. Effects of cropping systems and mowing stages, in factorial combination, on the specific biogas production $\left(\mathrm{nm}^{3} \mathrm{mgvs}^{-1}\right)$. Legend according to the note reported in Table 1.

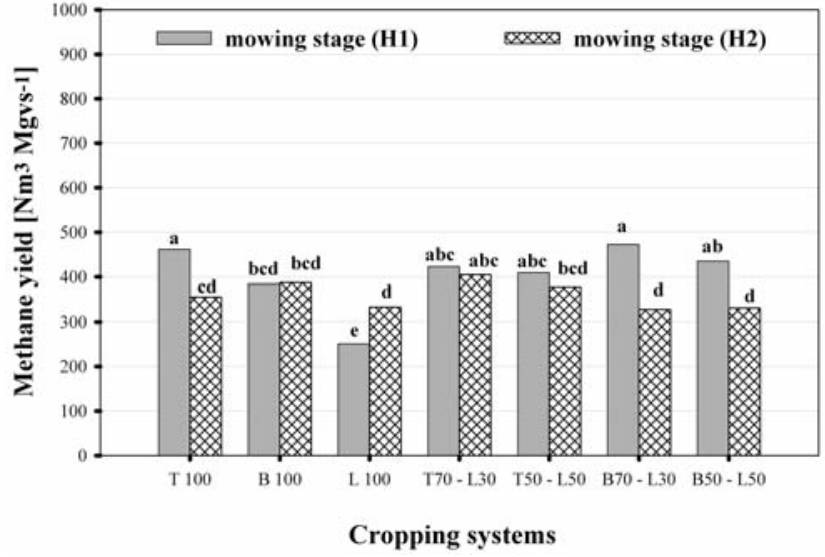

Figure 7. Effects of cropping systems and mowing stages, in factorial combination, on the specific methane production $\left(\mathrm{nm}^{3}\right.$ $\left.\mathrm{mg}_{\mathrm{vs}}{ }^{-1}\right)$. Legend according to the note reported in Table 1 .

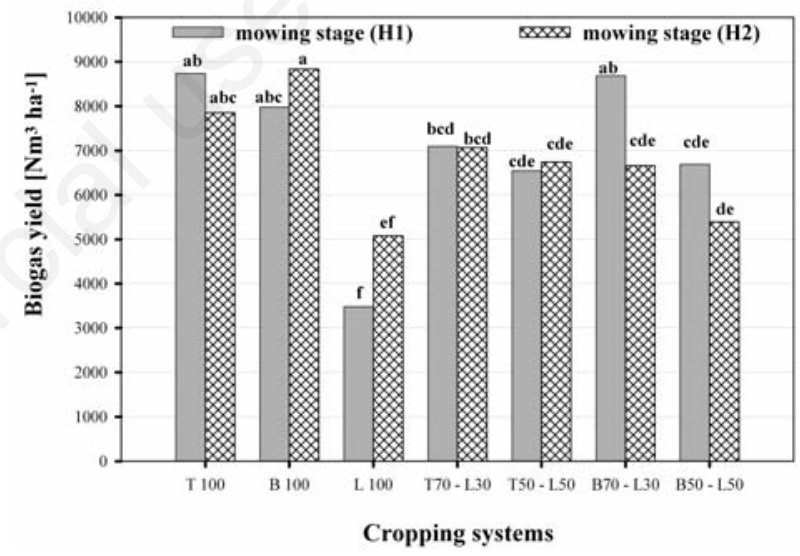

Figure 8. Effects of cropping systems and mowing stages, in factorial combination, on the per hectare biogas production $\left(\mathrm{nm}^{3}\right.$ $\left.h^{-1}\right)$. Legend according to the note reported in Table 1 .

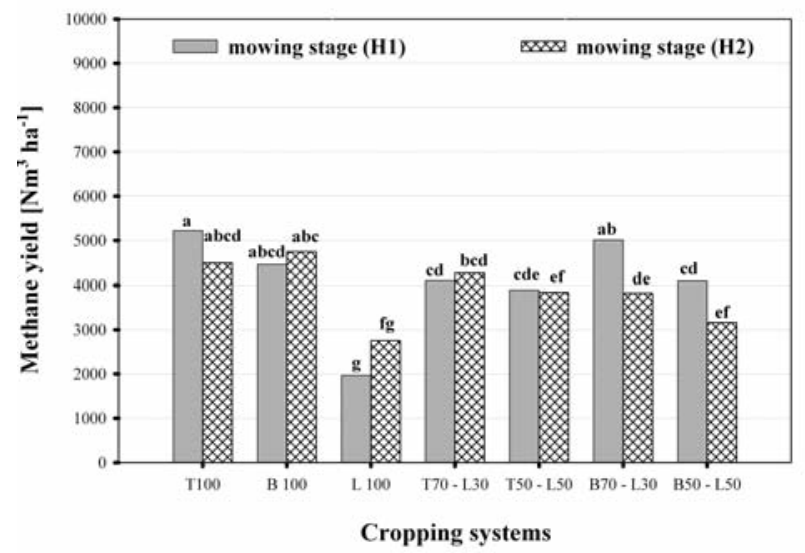

Figure 9. Effects of cropping systems and mowing stages, in factorial combination, on the per hectare methane production $\left(\mathrm{nm}^{3}\right.$ $\mathrm{ha}^{-1}$ ). Legend according to the note reported in Table 1 . 
The qualitative parameters related to the chemical composition of the ensiled biomass were identified and characterized considering their ability to influence biogas and methane production.

Ash content decreased with the progressing of the development stages of the crops and this may be due to the dilution effect of the mineral fraction into the DM of the crops (Ghanbari-Bonjar and Lee, 2003). This decrease corresponded to an increase in volatile solids content (with respect to DM) that could have a positive influence on biogas production.

Heiermann (2009) observed that $\mathrm{pH}$ was increasing with the progress of the crop development stages. This author have shown that in barley and triticale the $\mathrm{pH}$ values increased from 6.6 to 7.2 and from 6.6 to 7.1 , respectively, at the two subsequent development stages.

With specific reference to protein content, our data showed the same trend of the studies by Khorasani et al. (1997) that examined the influence of harvesting dates on the chemical composition of alfalfa, oat, barley and triticale silage. Their results have clearly indicated that as the crop was maturing its protein content was decreasing.

Other studies (Delogu et al., 2002), regarding triticale as herbage crop cultivated in a Mediterranean area (Po valley and Sardegna region, Italy), showed that in later development stages (from early spike-heading to milk-dough stages) grain filling had a significant diluting effect on crude proteins, cellulose and hemicellulose, while the process of crop physiological maturity induced an increase in the lignin content. Our results, considering the lignin content, are not in accordance with the data reported in this latter work, thus showing a decrease in lignin content in triticale from the first (milk stage) to the second (dough stage) harvesting. This divergence may be probably due to different environmental conditions or an inconsistent matching to the two phenological stages. However, other studies (Helm and Salmon, 2002) reported that in every crop (such as triticale and oat) the lignin content increased with plan maturity only until 3 weeks after the boot-stage and then declined.

The fibre content, especially lignin, has a key influence in the anaerobic digestion processes (Amon et al., 2002, 2007). In general, a decrease of lignin concentration can represent an important factor to enhance methane yields.

$\mathrm{XL}$ and XZ content recorded in our research on herbage monoculture are in accordance with those reported, for the same species, in other studies (Heierman et al., 2009).

The nitrogen content is very relevant in determining the activity of microorganisms involved in anaerobic digestion, consequently the most suitable concentration should be carefully determined. Many authors (Bardiya and Gaur, 1997; Schattauer and Weiland, 2004) reported that the optimum $\mathrm{C}: \mathrm{N}$ ratio for anaerobic digestion should be between 20 and 30 . When the biomass $\mathrm{C}: \mathrm{N}$ ratio is much higher, carbon cannot optimally be converted into methane. Not considering the legume in monoculture (that showed a lower ratio), the $\mathrm{C}: \mathrm{N}$ values in our research were always outside this optimum range. This was particularly evident in the second harvesting stage (40.7 on average) as compared with the first one (37.1 on average). In these cases, is generally suggested (Amon et al., 2007) to co-digest the biomass with other feedstock having a strict optimal C:N ratio that could help to avoid the problem. The ensiled biomass harvested at $\mathrm{H}_{1}$ (milk development stage) have shown biogas and methane yield higher than the one obtained at $\mathrm{H}_{2}$ (dough development stage). Our results are in accordance with Heiermann et al. (2009). These authors have conducted batch anaerobic digestion tests under mesophilic temperature conditions $\left(35^{\circ} \mathrm{C}\right)$ with different crops (barley, triticale, rye, alfalfa and maize). The results for triticale and barley showed an increase of specific biogas and methane yields, from anthesis to milk stage and a following decrease from milk to dough stage. The positive effect of harvesting time on the production of methane may be due (Chandler et al., 1980; Amon et al., 2005) to an increase in crude protein, starch and sugar content. Similarly, a reduction of lignin content could have a positive effect on specific biogas production because it negatively affects the anaerobic digestion process.

Our data have shown high specific biogas and methane yields for triticale as a single-crop, triticale-legume and barley-legume intercropping in the early harvesting (milk stage); while, legume monoculture has shown higher yield in the second harvesting stage.

The average specific biogas yields observed in this research for triticale $\left(772.6 \mathrm{~nm}^{3} \mathrm{mg}_{v \mathrm{~s}}{ }^{-1}\right)$ and barley $\left(687.7 \mathrm{~nm}^{3} \mathrm{mg}_{\mathrm{vs}}{ }^{-1}\right)$ at $\mathrm{H}_{1}$ stage were similar to the one reported by Heiermann et al. (2009) for the same crops (700 and $730 \mathrm{~nm}^{3} \mathrm{mg}_{\mathrm{vs}}{ }^{-1}$ for triticale and barley, respectively). The specific biogas yield, instead, was not in accordance with the data reported by 0slaj et al. (2010) for corn hybrids. This experiment was made in 2007 and investigated the amount of biogas and methane from different maize hybrids in several grain maturity stages. The reported biogas productions (526-602 $\mathrm{nm}^{3} \mathrm{mg}_{\mathrm{vs}}{ }^{-1}$ ) for corn (FAO 400, FAO 500) were generally lower than the ones recorded in our trial. Probably the ensilage process, conducted before batch testing, may have contributed to increase the specific methane production in our experiments. High methane yield was also obtained with barley-legume intercropping $\left(\mathrm{B}_{70}-\mathrm{L}_{30}\right)$ at $\mathrm{H}_{1}$ stage $\left(819.1 \mathrm{~nm}^{3} \mathrm{mg}_{\mathrm{vs}}{ }^{-1}\right)$ and it does not differ statistically, at a $5 \%$ probability level, from triticale in monoculture at the same harvest stage $\left(772.6 \mathrm{~nm}^{3} \mathrm{mg}_{\mathrm{vs}}{ }^{-1}\right)$.

Biogas and methane per hectare production $\left(\mathrm{nm}^{3} \mathrm{ha}^{-1}\right)$ were both affected by the cropping system as well as by the harvesting date in specific optimal combinations. The optimal harvesting of grasses was obtained when the specific methane yield (from one side) and the per hectare volatile solids production (from the other) reached a maximum value. There is not a general or straight forward solution: $T_{100}$ and $B_{70^{-}}$ $\mathrm{L}_{30}$ treatments gave a higher methane production $\left(5221.1 \mathrm{~nm}^{3} \mathrm{ha}^{-1}\right.$ and $5008.9 \mathrm{~nm}^{3}$ ha $^{-1}$ respectively) at $\mathrm{H}_{1}$; while considering $\mathrm{B}_{100}$ a higher methane production (equal to $4746.9 \mathrm{~nm}^{3} \mathrm{ha}^{-1}$ ) was obtained at $\mathrm{H}_{2}$.

The per hectare methane production recorded in this study has resulted significantly lower values than the one reported for maize $\left(7000-8000 \mathrm{~nm}^{3} \mathrm{ha}^{-1}\right)$ by other authors (Amon et al., 2007; Oslaj et al., 2010). These differences are probably due to higher per hectare dry matter yields reported for maize as compared to grasses.

\section{Conclusions}

The herbage crops enables a considerable biomass yield and moreover allows to under sown summer biomass crops (like maize, sorghum, sunflower), thus significantly rising the total amount of biomass collectable in the course of the year and to be destined to anaerobic digestion. This intensification of the cropping systems can still be considered sustainable especially when the winter herbage cultivation consists of a mixture of species (intercropping) where grasses and legumes are both represented.

The effect of grasses is to increase the herbage productivity while legume is exerting a fundamental nutritional function, specifically with respect to nitrogen availability into soil and for plants, both directly in the mixture and in the subsequent cultivation cycles. In this context, our work validated the suitability of a winter intercropping system (grass-legume) in southern Italy, in order to supply highly productive and qualitative feedstock for anaerobic digestion and obtain considerable biogas/biomethane yield.

Particularly interesting, from the side of both agricultural manage- 
ment and biogas technological procedure, was the application of intercropping, considering a well-balanced grass-legume mixture, with the legume component not exceeding approximately the $30 \%$ of the mixture. Biogas and methane per hectare production $\left(\mathrm{nm}^{3} \mathrm{ha}^{-1}\right)$ were both affected by the cropping system as well as by the harvesting date in specific optimal combinations. Our research showed high specific biogas and methane yields for triticale as a single-crop, triticale-legume and barley-legume intercropping in the first harvesting date (milk stage); instead, for barley monocrop treatments better harvesting date appears to be the second (waxy stage).

\section{References}

Amon T, Amon B, Kryvoruchko V, Machmuller A, Hopfner-Sixt K, Bodiroza V, Hrbek R, Friedel J, Potsch E, Wagentristl H, Schreiner M, Zollitsch W, 2007. Methane production through anaerobic digestion of various energy crops grown in sustainable crop rotations. Biores. Technol. 98:3204-12.

Amon T, Kryvoruchko V, Amon B, Buga S, Amin A, Zollitsch W, Mayer K, Potsch E, 2004. Biogasertrageauslandwirtschaftlichen Gargutern. pp. 21-26 in Proc. 10th Alpenlandische Expertenforumzum Thema Biogasproduktion.

Amon T, Kryvoruchko V, Amon B, Moitzi G, Lyson D, Hackl E, Jeremic D, Zollitsch W, Potsch E, 2003. Optimierung der Biogaserzeugungaus den Energiepflanzen Mais und Kleegras. Final Report 77. July 2003. Bundesministeriumsfu“ $r$ Land- und Forstwirtschaft, Umwelt- und Wasserwirtschaft. Research Project No. 1249.

Amon T, Kryvoruchko V, Amon B, Moitzi G, Lyson D, Hackl E, Jeremic D, Zollitsch W, Potsch E, Mayer K, Plank J, 2002. Methanbildungsvermo"gen von Mais - Einfluss der Sorte, der Konservierung und des Erntezeitpunktes. Final Report 47. On behalf of Pioneer SaatenGes.m.b.H. Parndorf (Austria).

Amon B, Kryvoruchko V, Amon T, Zechmeister-Boltenstern S, 2006. Methane, nitrous oxide and ammonia emissions during storage and after application of dairy cattle slurry and influence of slurry treatment. Agr. Ecosyst. Environ. 112:153-62.

Amon T, Kryvoruchko V, Bodiroza V, Amon B, 2005. MethanerzeugungausGetreide, Wiesengras und Sonnenblumen. Einfluss des Erntezeitpunktes und der Vorbehandlung. pp. 343-348 in: 7th Meet. Bau, Technik und Umwelt in der landwirtschaftlichen Nutztierhaltung 2005.

AOAC, 1990. Available from: http://www.aoac.org/News/ AOAC_ 11022012.htm

AOAC, 2000. Available from: http://www.aoac.org/News/A0AC_1102 2012.htm

Balestrieri F, Marini D, 1996. Metodi di analisi chimica dei prodotti alimentari. Monolite Ed., Roma, Italy.

Balsari P, Bonfanti P, Bozza E, Sangiorgi F, 1983. Evaluation of the influence of animal feeling on the performances of a biogas installation (mathematical model). Page 7 in 3rd Int. Symp. on Anaerobic Digestion, Boston, MA, USA (abstr.).

Bardiya N, Gaur AC, 1997. Effects of carbon and nitrogen ratio on rice straw biomethanation. J. Rural Energy 4:1-16.

Bocchi A, Lazzoroni G, Bearardo N, Maggiore T, 1996. Evaluation of triticale as forage plant through the analysis of the kinetics of some qualitative parameters from stem elongation to maturity. In: $\mathrm{H}$. Guedes-Pinto, N. Darvey, V.P. Carnide (eds.) Triticale: Today and Tomorrow. Kluwer Acedemic Publishers, Dordtrecht, The Netherlands. pp 827-834.

Chalk PM, 1998. Dynamics of biologically fixed N in legume-cereal rotations: a review. Aust. J. Agric. Res. 49:303-16.
Chandler JA, Jewell WJ, Grossett JM, Vansoest PJ, Robertson JB, 1980. Predicting methane fermentation biodegradability. Biotechnology and Bioengineering Symposium, New York, NY, USA, 10:93-107.

Chen Y, Cheng JJ, Creamer KS, 2008. Inhibition of anaerobic digestion process: a review. Bioresour. Technol. 99:4044-64.

De Clerk J, 1963. Course de brasserie, 2nd ed. Universitè catholique de Louvain, Louvain-la-Neuve, Belgium.

Delogu G, Faccini N, Faccioli P, Reggiani F, Lendini M, Berardo N, Odoardi M, 2002. Dry matter yield and quality evaluation at two phenological stages of forage triticale grown in the Po Valley and Sardinia, Italy. Field Crops Res. 74:207-15.

DIN, 1985. Bestimmung des Faulverhaltens "Schlamm und Sedimente". Num 38414. Beuth Verlag GmbH, Berlin, Germany.

DIN, 2006-2007. DIN EN ISO 16634. Cereals, pulses, milled cereal products, oilseeds and animal feeding stuffs - Determination of the total nitrogen content by combustion according to the Dumas principle and calculation of the crude protein content, Standard. Beuth Verlag $\mathrm{GmbH}$, Berlin, Germany.

Dolciotti I, Mambelli S, Grandi S, Venturi G, 1998. Comparison of two Sorghum genotypes for sugar and fiber production. Ind. Crop. Prod. 7:265-72.

El Bassam N, 1998. Energy plant species-their use and impact on environment. James \& James Science Publisher Ltd, London, UK.

Ghanbari-Bonjar A, Lee HC, 2003. Intercropped wheat (Triticum aestivum L.) and bean (Vicia faba L.) as a whole-crop forage: effect of harvest time on forage yeld and quality. Grass Forage Sci. 58:28-36.

Goering HK, van Soest PJ, 1970. Forage fiber analysis (apparatus, reagents, procedures and some applications). USDA Agricolture Handbook. Agricultural Research Service, Handbook No. 379, Washington, DC, USA.

Hauggaard-Nielsen H, Andersen MK, Jornsgaard B, Jensen ES, 2006. Density and relative frequency effects on competitive interactions and resource use in pea-barley intercrops. Field Crops Res. 95:25667.

Heiermann M, Plochlm M, Linke B, Schelle H, Herrmann C, 2009. Biogas crops-Part I: Specifications and suitability of field crop for anaerobic digestion. Agric. Engine. Int. 11:1087.

Helm JH, Salmon DF, 2002. Cereal Silage Options for Western Canada. Adv. Dairy Technol. 14:229-39.

Herrmann C, Heiermann M, Idler C, Scholz V, 2007. Parameters influencing substrate quality and biogas yield. In: K. Maniatis (ed.) 15th European Biomass Conference \& Exhibiton "From Research to Market Development”, Berlin, Germany, pp 809-19.

Jensen ES, 1996. Grain yield, symbiotic $\mathrm{N}_{2}$ fixation and interspecific competition for inorganic $\mathrm{N}$ in pea-barley intercrops. Plant Soil 182:25-38

Kala P, 2011. The required characteristics of ensiled crops used as a feedstock for biogas production: a review. J. Agrobiol. 28:85-96.

Khorasani GR, Jedel PE, Helm JH, Kennelly JJ, 1997. Influence of stage of maturity on yeld components and chemical composition of cereal grain silage. Can. J. Animal Sci. 77:59-267.

Liu T, Sung S, 2002. Ammonia inhibition on thermophilic aceticlastic methanogens. Water Sci. Technol. 45:113-20.

Oslaj M, Mursec B, Vindis P, 2010. Biogas production from maize hybrids. Biomass Bioenergy 34:1538-45.

Pristeri A, Dahlmann C, von Fragstein P, Gooding MJ, HauggaardNielsen H, Kasyanova E, Monti M, 2006. Yield performance of Faba bean-Wheat intercropping on spring and winter sowing in European organic farming system. Proceedings of European Joint Organic Congress, 30-31 May 2006, Odense, Denmark.

Prochnow A, Heiermann M, Plöchl M, Linke B, Idler C, Amon T, Hobbs $\mathrm{P}, 2009$. Bioenergy from permanent grassland - A review: 1. Biogas Bioresour. Technol. 100:4931-44. 
Sadocchi S, 1981. Manuale di analisi statistica multivariata per le scienze sociali, Franco Angeli Editore, Milano, Italy. p 274.

Schattauer A, Weiland P, 2004. Handreichung Biogasgewinnung und nutzung. Final Report. Förderkennzeichen 22027200. Fachagentur Nachwachsende Rohstoffe e.V. (Ed.), Gülzow, pp 4/1-4/13.

Senaratne R, Hardarson G, 1988. Estimation of residual N effect of feba bean and pea on two succeeding cereals using 15-N methodology. Plant Soil 110:81-9.

Stagnari F, Onofri A, Jemison J, Monotti M, 2007. Improved multivariate analyses to discriminate the behaviour of faba bean varieties. Agron. Sustain. Dev. 27:387-97.

Stulpanagel R, 1984. Proposal of growth stages for Vicia faba. In: P.D.
Hebblethwaite, T.C.K. Dawkines, M.C. Heath and G. Lockwood (eds.) Vicia faba: Agronomy, physiology and breeding. Martinus Nijhof, The Hague, Netherlands, pp 9-14.

Sung S, Liu T, 2003. Ammonia inhibition on thermophilic digestion. Chemosphere 53:43-52.

Vandermeer J, 1989. The ecology of intercropping. Cambridge University Press, Cambridge, UK.

Zadok JC, Change TT, Konzak CF, 1974. A decimal code for the growth stages of cereals. Weed Res. 14:415-21.

Ward AJ, Hobbs PJ, Holliman PJ, Jones DL, 2008. Optimisation of the anaerobic digestion of agricultural resources. Bioresour. Technol. 99:7928-40. 